\title{
NON-CATALYTIC ONE-POT SYNTHESIS OF POLYHYDROXY ESTOLIDES FROM OLEIC ACID
}

HOONG SENG SOI*; YEONG SHOOT KIAN* and HAZIMAH ABU HASSAN

\begin{abstract}
Polyhydroxy estolides were successfully synthesised from oleic acid through a non-catalytic one-pot method. Gel permeation chromatography (GPC) analysis showed that the yield of the polyhydroxy estolides was about $72 \%$ and the number average molecular weight $\left(M_{n}\right)$ of the product ranges between $1000-2200$ Da. Other instrumental analyses such as nuclear magnetic resonance (NMR), Fourier transform infraRed (FTIR) and Matrix-assisted laser desorption/ionization-time of flight (MALDI-TOF) as well as acid value analysis revealed that the prepared polyhydroxy estolides was oligomers of dihydroxystearic acid linked by ester groups and further confirmation of the oligomers structure was achieved by reduction and saponification reactions.
\end{abstract}

Keywords: epoxidation, oxirane ring opening, self-oligomerisation.

Date received: 20 February 2016; Sent for revision: 5 April 2016; Received in final form: 15 September 2016; Accepted: 21 November 2016.

\section{INTRODUCTION}

Estolides are products of the reaction between the carboxylic acid functionality of a fatty acid with the alkene functionality of another fatty acid to form an ester linkage. Estolides are simply intermolecular esters of at least two fatty acids linked by an ester functionality that can be illustrated by Figure 1 (Cermak et al., 2001). Estolides have been prepared and used in a number of commercial applications such as lubricants, hydraulic fluids, coatings, food emulsifiers, pigment dispersants, cosmetic and personal care products (Zerkowski, 2008).

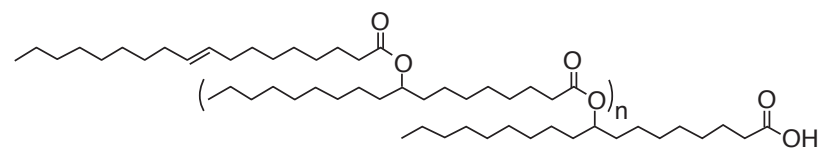

Figure 1. Estolides made from oleic acid.

\footnotetext{
* Malaysian Palm Oil Board, 6 Persiaran Institusi, Bandar Baru Bangi, 43000 Kajang,

Selangor, Malaysia.

E-mail: sengsoi@mpob.gov.my

* 7 Jalan 3/2L, 43650 Bandar Baru Bangi, Selangor, Malaysia.
}

Estolides are normally synthesised either through acid-catalysed or enzyme-catalysed reactions. The acid-catalysed method utilised unsaturated fatty acids such as oleic acid as the feedstock and employed perchloric acid as the catalyst. The method yielded $76 \%$ of estolides after $2 \mathrm{hr}$ of reaction at $50^{\circ} \mathrm{C}$ (Isbell et al., 1994). Another approach to prepare estolides was through the esterification reaction between plant oil that contains hydroxyl groups on its triglyceride molecule such as castor oil and a fatty acid such as oleic acid (Isbell et al., 2002). In addtion, estolides can also be produced by intermolecular esterification of hydroxy fatty acid such as ricinoleic acid at $200^{\circ} \mathrm{C}$ (Modak et al., 1965).

The enzymatic approach used lipases as the catalyst. The suitable starting materials were fatty acids with hydroxyl functionality such as ricinoleic acid. For example, lesquerolic acid was converted to estolides in the presence of Pseudomonas sp. lipase after $65 \mathrm{hr}$ of reaction at $22^{\circ} \mathrm{C}$ that produced $62 \%$ yield (Hayes et al., 1995). Another example employed Candida rugosa lipase to yield $50 \%$ estolides from ricinoleic acid after five days of reaction at $60^{\circ} \mathrm{C}$ (Kiatsimkul et al., 2008). 
Polyhydroxy estolides (PE) is another type of estolides, where it has pendant hydroxyl groups on its fatty acid chains as illustrated by Figure 2. The pendant hydroxyl groups of $\mathrm{PE}$ offer chances to further derivatise with other functional groups. This interesting molecule can be synthesised from intermolecular esterification between hydroxyl and carboxylic acid groups of 9,10-dihydroxystearic acid at $180^{\circ} \mathrm{C}$ (Awang et al., 2007). The compound 9,10-dihydroxystearic acid can be prepared from oleic acid through reaction with hydrogen peroxide and acetic acid (Awang et al., 2001). PE was used as emulsifier and thickener in water-in-oil emulsion for cosmetic and personel care products. It was also used as anti-rust additive in metal cutting fluid applications (Ismail et al., 2015). In addition, PE potentially could also be used for applications found suitable for estolides as mentioned above

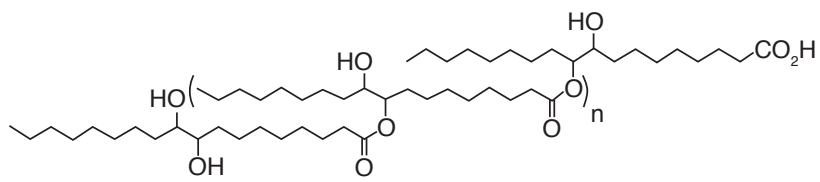

Figure 2. Idealised structure of polyhydroxy estolides.

Another method of preparing PE is through oxirane ring opening of epoxidised fatty esters with fatty acids at elevated temperature. A study by Pages and Alfos (2001) detailed the preparation of estolides from epoxidised high oleic methyl ester, which was ring opened by oleic acid at $175^{\circ} \mathrm{C}$ without catalyst for $17 \mathrm{hr}$ to yield about $90 \%$ estolides.

In general, current methods to make PE from oleic acid involves several synthetic steps such as epoxidation and esterification followed by respective auxiliary purification steps that would incur higher production cost. In addition, the esterification and oxirane ring opening with fatty acid requires high reaction temperature to yield the desired PE that contribute to higher production cost.

Hence, it would be advantageous to be able to produce PE that involves less synthetic and purification steps as compared to existing technologies. Furthermore, it would also be desirable to prepare the targeted product at a lower reaction temperature in order to lower production cost. Therefore, in this study, PE will be produced from oleic acid through a simple non-catalytic onepot process at a lower temperature, which will significantly reduce the production cost of PE as compared to current methods.

\section{EXPERIMENTAL SECTION}

\section{Materials}

All purchased chemicals were used as received. The following chemicals were purchased from sources indicated: oleic acid (OA) 90\% (Aldrich), hydrogen peroxide $(30 \% \mathrm{w} / \mathrm{v}$, Fischer), lithium aluminum hydride solution $\left(\mathrm{LiAlH}_{4}, 1.0 \mathrm{M}\right.$ in THF, Aldrich), deuterated chloroform $\left(\mathrm{CDCl}_{3}, 99.8 \%\right.$, Aldrich), deuterated dimethyl sulfoxide (DMSO- ${ }_{6^{\prime}}$ 99.9\% Aldrich).

\section{General Procedure}

Thin layer chromatography (TLC) was carried out on Merck $0.25 \mathrm{~mm}$ silica layer foiled-backed 60F-254 TLC sheets developed from potassium permanganate. Column chromatography was performed with Davisil silica gel Grade 633 pore size $60 \AA$ A particle size $40-63 \mu \mathrm{m}$.

\section{Synthesis of Polyhydroxy Estolides (PE) from Oleic Acid}

OA (5 g, $17.7 \mathrm{mmol})$ and hydrogen peroxide $(30 \% \mathrm{w} / \mathrm{w}, 10 \mathrm{~g}, 88 \mathrm{mmol})$ were weighed into a round bottom flask. The mixture was stirred and heated at $80^{\circ} \mathrm{C}$ for three days. The mixture was poured into a separating funnel and ethyl acetate $(20 \mathrm{ml})$ as well as deionised water $(20 \mathrm{ml})$ were added to it. The organic layer was separated from the aqueous layer. The organic layer was dried over anhydrous magnesium sulphate $\left(\mathrm{MgSO}_{4}\right)$ and ethyl acetate was removed in vacuo to yield a colourless liquid labelled as PE (PE) $(5 \mathrm{~g}) v_{\text {max }} / \mathrm{cm}^{-1} 3467(\mathrm{OH})$ 2923, 2854 (C-H) 1733, 1708 (C=O) $1174(\mathrm{C}-\mathrm{O}) 723$ $\left(\mathrm{CH}_{2}\right) ;{ }^{1} \mathrm{H} \mathrm{NMR}\left(400 \mathrm{MHz}, \mathrm{CDCl}_{3}\right): \delta \mathrm{H}=4.87-4.80$ $(2 \mathrm{H}, \mathrm{m}, \mathrm{HCOC}=\mathrm{O}), 3.63-3.55(2 \mathrm{H}, \mathrm{m}, \underline{\mathrm{HCO}})$ 3.45-3.38 $(2 \mathrm{H}, \mathrm{m}, \underline{\mathrm{HCO}}), 2.32\left(6 \mathrm{H}, \mathrm{t}, J=7.1 \mathrm{~Hz}, \mathrm{O}=\mathrm{CC}_{\mathrm{H}_{2}} \mathrm{CH}_{2}\right)$, $1.68-1.56\left(6 \mathrm{H}, \mathrm{m}, \mathrm{O}=\mathrm{CCH}_{2} \underline{\mathrm{H}}_{2} \mathrm{CH}_{2}\right), 1.54-1.20(72 \mathrm{H}$, $\left.\mathrm{m}, \mathrm{CH}_{2} \mathrm{CH}_{2} \mathrm{CH}_{2}\right), 0.88\left(12 \mathrm{H}, \mathrm{t}, J=6.0 \mathrm{~Hz}, \mathrm{CH}_{2} \mathrm{CH}_{3}\right)$; ${ }^{13} \mathrm{C}$ NMR $\left(100 \mathrm{MHz} \mathrm{CDCl}_{3}\right): \delta \mathrm{C}=179.0,173.9(\mathrm{C}=\mathrm{O})$, $76.2(\mathrm{H} \underline{C O C}=\mathrm{O}), 74.6,72.5(\mathrm{H} \underline{\mathrm{C}}-\mathrm{O}), 34.0\left(\mathrm{O}=\mathrm{C}^{\mathrm{C}} \mathrm{H}_{2}\right)$, $24.6\left(\mathrm{O}=\mathrm{CCH}_{2} \mathrm{CH}_{2} \mathrm{CH}_{2}\right), \quad 31.8, \quad 29.1,24.6,22.6$ $\left(\mathrm{CH}_{2} \mathrm{CH}_{2} \mathrm{CH}_{2}\right), 14.0\left(\mathrm{CH}_{2} \mathrm{CH}_{3}\right) ; \mathrm{m} / z\left(\mathrm{ES}^{+}\right)\left[\mathrm{M}+\mathrm{Na}^{+}\right]$ $(\mathrm{n}=3)$ required 935.7527 , found 935.7519.

\section{Saponfication of Polyhydroxy Estolides}

PE (2.5 g, $2.06 \mathrm{mmol})$ were dissolved in $20 \mathrm{ml}$ tetrahydrofuran in a $100 \mathrm{ml}$ round bottom flask equipped with a magnetic stirrer. Then $1.3 \mathrm{~g}$ (32.5 $\mathrm{mmol}$ ) of sodium hydroxide was dissolved in 20 $\mathrm{ml}$ deionised water and this sodium hydroxide solution was added to the round bottom flask. The mixture was heated to $80^{\circ} \mathrm{C}$ for $12 \mathrm{hr}$ under reflux, which was then acidified to $\mathrm{pH} 1$ with $2 \mathrm{M} \mathrm{HCl}$. The reaction mixture was poured into a separating funnel and the aqueous layer was separated from the organic layer. The aqueous layer was extracted with chloroform $\left(\mathrm{CHCl}_{3}\right)(100 \mathrm{ml})$ and the $\mathrm{CHCl}_{3}$ extract was combined with the organic layer, which was dried over anhydrous $\mathrm{MgSO}_{4}$. The organic layer was filtered and the solvent removed 
in vacuo to yield crude product $(2.05 \mathrm{~g})$. A small amount of crude product $(250 \mathrm{mg}$ ) was purified by column chromatography [petroleum ether $\left(40^{\circ} \mathrm{C}-60^{\circ} \mathrm{C}\right) /$ ethyl acetate, $\left.7: 3\right)$ to yield purified 9,10-dihydroxystearic acid (DHSA) (182 mg, 0.576 mmol, 57\%] as a white solid. Rf 0.3 [petroleum ether $\left(40^{\circ} \mathrm{C}-60^{\circ} \mathrm{C}\right) /$ ethyl acetate, $\left.7: 3\right] ; v_{\max } / \mathrm{cm}^{-1} 3292$ $(\mathrm{O}-\mathrm{H})$ 2915, 2847 (C-H) $1716(\mathrm{C}=\mathrm{O}) 1467\left(\mathrm{CH}_{2}\right) 1076$ (C-O) $719\left(\mathrm{CH}_{2}\right) ;{ }^{1} \mathrm{H}$ NMR (400 MHz, DMSO-d $)$ : $\delta \mathrm{H}$ $=12.0(1 \mathrm{H}, \mathrm{s}, \mathrm{COO} \underline{\mathrm{H}}), 3.24-3.18(2 \mathrm{H}, \mathrm{m}, \underline{\mathrm{HCOH}})$, $2.2\left(2 \mathrm{H}, \mathrm{t}, J=7.5 \mathrm{~Hz}, \mathrm{O}=\mathrm{CC} \underline{\mathrm{H}}_{2}\right), 1.65-1.55(2 \mathrm{H}, \mathrm{m}$, $\left.\mathrm{HOOCCH}_{2} \mathrm{CH}_{2}\right), \quad 1.50-1.35\left(2 \mathrm{H}, \mathrm{m}, \mathrm{HOCHC} \underline{\mathrm{H}}_{2}\right)$, 1.35-1.20 (20H, m, $\left.\mathrm{CH}_{2} \mathrm{CH}_{2} \mathrm{CH}_{2}\right), 0.85(3 \mathrm{H}, \mathrm{t}, J=7.5$ $\left.\mathrm{Hz}, \mathrm{CH}_{2} \mathrm{CH}_{3}\right) ;{ }^{13} \mathrm{C}$ NMR $(100 \mathrm{MHz}$ DMSO-d $)$ : $\delta \mathrm{C}$ $=174.5(\underline{\mathrm{C}}=\mathrm{O}), 73.1(\underline{\mathrm{C}}-\mathrm{OH}), 33.6\left(\mathrm{O}=\mathrm{C}_{\underline{C}} \mathrm{H}_{2}\right), 31.3$ $\left(\mathrm{HOCHCH}_{2}\right), 24.3\left(\mathrm{O}=\mathrm{CCH}_{2} \mathrm{CH}_{2} \mathrm{CH}_{2}\right), 29.1,28.0$, $22.6\left(\mathrm{CH}_{2} \mathrm{CH}_{2} \mathrm{CH}_{2}\right), m / z\left(\mathrm{ES}^{+}\right),\left[\mathrm{M}+\mathrm{Na}^{+}\right]$required 339.2511, found 339.2506; melting point $=95^{\circ} \mathrm{C}$ $96^{\circ} \mathrm{C}$ (literature; McKay et al., 1948): $94^{\circ} \mathrm{C}$ ) [found: $\mathrm{C}, 68.3 \% ; \mathrm{H}, 11.5 \% ; \mathrm{C}_{18} \mathrm{H}_{36} \mathrm{O}_{4}$ required $\mathrm{C}, 68.3 \% ; \mathrm{H}$, $11.5 \% ; \mathrm{O}, 20.2 \%]$.

\section{Reduction of Polyhydroxy Estolides}

PE (2.5 g, $2.06 \mathrm{mmol})$ was dissolved in $25 \mathrm{ml}$ dry tetrahydrofuran in a $100 \mathrm{ml}$ round bottom flask equipped with a magnetic stirrer under nitrogen gas atmosphere. The reactant was cooled to $0^{\circ} \mathrm{C}$ with an ice bath. Then, $40 \mathrm{ml}$ of $\mathrm{LiAlH}_{4}(1 \mathrm{M}, 40$ $\mathrm{mmol}$ ) was slowly added to the reactant while the reactant was being stirred. After the addition was completed, the reaction temperature was raised to room temperature and held for $24 \mathrm{hr}$. After $24 \mathrm{hr}$, the excess $\mathrm{LiAlH}_{4}$ was decomposed with deionised water and $20 \mathrm{ml}$ of $\mathrm{H}_{2} \mathrm{SO}_{4}$ (10\% concentration) was added to the reactant mixture. The reaction mixture was poured into separating funnel and the aqueous layer was separated from the organic layer. The aqueous layer was extracted with $\mathrm{CHCl}_{3}(2 \times 100$ $\mathrm{ml}$ ) and the $\mathrm{CHCl}_{3}$ extract was combined with the organic layer, which was dried over anhydrous $\mathrm{MgSO}_{4}$. The organic layer was filtered and the solvent removed in vacuo to yield crude product (1.63 g). A small amount of crude product $(250 \mathrm{mg}$ ) was purified by column chromatography [petroleum ether $\left(40^{\circ} \mathrm{C}-60^{\circ} \mathrm{C}\right) /$ ethyl acetate, 8:2] to yield purified 1,9,10-trihydroxystearol (THS) (175 mg, $0.58 \mathrm{mmol}, 46 \%$ ) as a white solid. R 0.3 [petroleum ether $\left(40^{\circ} \mathrm{C}-60^{\circ} \mathrm{C}\right) /$ ethyl acetate, $\left.8: 2\right] ; v_{\max } / \mathrm{cm}^{-1} 3340$ (O-H) 2915, 2847 (C-H) $1463\left(\mathrm{CH}_{2}\right) 1057(\mathrm{C}-\mathrm{O}) 723$ $\left(\mathrm{CH}_{2}\right) ;{ }^{1} \mathrm{H}$ NMR $\left(400 \mathrm{MHz}, \mathrm{CDCl}_{3}\right): \delta \mathrm{H}=3.60(2 \mathrm{H}, \mathrm{t}$, $J=6.6 \mathrm{~Hz}, \underline{\mathrm{HCOH}}), 3.43-3.38(2 \mathrm{H}, \mathrm{m}, \underline{\mathrm{HCOH}}), 1.64-$ $1.51\left(2 \mathrm{H}, \mathrm{m}, \mathrm{HOCC} \underline{\mathrm{H}}_{2}\right), 1.50-1.42\left(2 \mathrm{H}, \mathrm{m}, \mathrm{HOCC}_{2}\right)$ $1.40-1.20\left(24 \mathrm{H}, \mathrm{m}, \mathrm{CH}_{2} \mathrm{CH}_{2} \mathrm{CH}_{2}\right), 0.87(3 \mathrm{H}, \mathrm{t}, J=$ $\left.7.5 \mathrm{~Hz}, \mathrm{CH}_{2} \mathrm{C}_{3}\right) ;{ }^{13} \mathrm{C} \mathrm{NMR}\left(100 \mathrm{MHz}^{2} \mathrm{CDCl}_{3}\right): \delta_{\mathrm{C}}=$ 72.7, $62.4(\underline{\mathrm{C}}-\mathrm{OH}), 33.0,32.5\left(\mathrm{HOCHCH}_{2}\right), 29.0$, 28.7, 25.1, $22.6\left(\mathrm{CH}_{2} \mathrm{CH}_{2} \mathrm{CH}_{2}\right), 15.0\left(\mathrm{CH}_{2} \mathrm{CH}_{3}\right) ; \mathrm{m} / \mathrm{z}$ $\left(\mathrm{ES}^{+}\right),\left[\mathrm{M}+\mathrm{Na}^{+}\right]$required 325.2713 , found 325.2714 ; melting point $=70^{\circ} \mathrm{C}-82^{\circ} \mathrm{C}$ (literature; Julietti et al.,
1960) : $82^{\circ} \mathrm{C}$ ) [found: $\mathrm{C}, 71.3 \% ; \mathrm{H}, 12.4 \% ; \mathrm{C}_{18} \mathrm{H}_{38} \mathrm{O}_{4}$ required $\mathrm{C}, 71.5 \% ; \mathrm{H}, 12.7 \% ; \mathrm{O}, 15.9 \%]$.

\section{Characterisation}

Infra-red spectra were recorded as solid or liquid on Perkin-Elmer Spectrum100 FTIR spectrometer and absorption maxima $\left(v_{\max }\right)$ are recorded in wavenumbers $\left(\mathrm{cm}^{-1}\right)$. Solids were compressed into a thin tablet and non-volatile liquids were analysed as thin film over diamond attenuated total reflectance (ATR) top plate. Mass spectrometry of low resolution was recorded on Bruker Esquire ESI 2000 in which molecular ions, fragment ions and other major peaks are recorded as mass/charge $(\mathrm{m} / \mathrm{z})$ ratios. High resolution mass spectrometry was achieved by using Bruker MaXis instrument to carry out accurate mass analysis.

Proton $\left({ }^{1} \mathrm{H}\right)$ and carbon $\left({ }^{13} \mathrm{C}\right)$ nuclear magnetic resonance (NMR) spectroscopy were recorded on Bruker DPX-400 at $400 \mathrm{MHz}$ and $100 \mathrm{MHz}$ respectively at $298 \mathrm{~K}$ with approximately $10 \% \mathrm{w} / \mathrm{v}$ solutions in deuterated NMR solvents. Chemical shifts are quoted in ppm relative to internal standard tetramethylsilane (TMS) and reference to the residual solvent. All coupling constant are quoted in hertz $(\mathrm{Hz})$. The ${ }^{1} \mathrm{H}$ and ${ }^{13} \mathrm{C}$ NMR assignments were routinely confirmed by ${ }^{1} \mathrm{H}-{ }^{1} \mathrm{H}$ (COSY) and ${ }^{1} \mathrm{H}-{ }^{13} \mathrm{C}$ (HMQC) data.

Matrix-assisted laser desorption/ionisationtime of flight mass spectrometry (MALDI-TOFMS) measurement was performed with a Bruker Daltonics Ultraflex II TOF/TOF mass spectrometer equipped with a nitrogen laser delivering 3-ns laser pulses at $337 \mathrm{~nm}$. Sample of $5 \mathrm{mg}$ was dissolved in $100 \mu \mathrm{l}$ tetrahydrofuran (THF) and $50 \mathrm{mg}$ of 2,5-dihydroxybenzoic acid (DHB) as the matrix was dissolved in $200 \mu$ tetrahydrofuran. Sample solution $(5 \mu \mathrm{l})$ and matrix solution $(20 \mu \mathrm{l})$ were mixed and $0.5 \mu \mathrm{l}$ of this mixture was spotted on the target plate and analysed. The sample was irradiated with 300600 pulsed laser shots at a $20 \%$ laser power and was measured in reflectron ion mode and was calibrated against poly (ethylene glycol) methyl ether.

Gel permeation chromatography (GPC) with THF as the eluent was performed on an Agilent 390MDS that has an autosampler and a PLgel $5.0 \mu \mathrm{m}$ bead-size guard column $(50 \times 7.5 \mathrm{~mm})$, followed by two linear $5.0 \mu \mathrm{m}$ bead-size PLgel Mixed D columns $(300 \times 7.5 \mathrm{~mm})$ and a differential refractive index detector. Analysis was performed using THF (2\% $\mathrm{v} / \mathrm{v}$ triethylamine) as the eluent at $30^{\circ} \mathrm{C}$ with a flow rate of $1 \mathrm{ml} \mathrm{min}^{-1}$. The GPC system was calibrated using linear poly(methyl methacrylate) (PMMA) EasiVial standards (Agilent Ltd) range from 200 to $10^{5} \mathrm{Da}$ and polystyrene (PS) EasiVial standards (Agilent Ltd) range from 162 to $10^{5} \mathrm{Da}$. Data were collected and analysed using Cirrus GPC/SEC software (version 3.3). 
Wet chemical analysis was performed according to the AOCS official methods (AOCS, 2009): acid value (AV), Te 1a-64 (89); hydroxyl value (OHV), Cd I3-60(89).

\section{RESULTS AND DISCUSSION}

\section{Non-catalytic One-pot Synthesis of Polyhydroxy Estolides from Oleic Acid}

A study (Warwel et al., 1995) reported that unsaturated fatty acids such as OA can be epoxidised in the presence of $\mathrm{H}_{2} \mathrm{O}_{2}$ with enzyme (Novozym 435) as the catalyst. The enzyme catalysed the formation of peracid from oleic acid with $\mathrm{H}_{2} \mathrm{O}_{2}$ as the source of oxygen. The newly formed oleic peracid in turn epoxidised the alkene group of another fatty acid. Based on this literature, a study was conducted to determine whether OA can form oleic peracid and 'self-epoxidised' as well as forming PE through epoxide ring opening without any catalyst (enzymatic or chemical). Therefore, OA was reacted with hydrogen peroxide at $80^{\circ} \mathrm{C}$ without any catalyst for one day in an attempt to yield PE.
The product of the reaction was subjected to NMR and GPC analysis. Analysis results based on ${ }^{1} \mathrm{H}$ NMR spectrum (Figure 3) showed some of the alkene group of OA still remained unreacted at 5.34 ppm. However, the same ${ }^{1} \mathrm{H}$ NMR spectrum also showed the formation of epoxide group at $2.93 \mathrm{ppm}$, which indicated that oleic acid can 'self-epoxidised' in the presence of hydrogen peroxide without any catalyst. In addition, the spectrum also exhibited the formation of ester and hydroxyl groups respectively at $4.85 \mathrm{ppm}$ and 3.4 - $3.6 \mathrm{ppm}$.

GPC analysis of the product showed a yield of only $43 \%$ of PE with the rest made up of the starting material. Based on the encouraging NMR and GPC results from the one day reaction, the same reaction was prolonged to three days (Figure 4) in order to fully react all the alkene and epoxide groups of the reactant, which should contribute to higher PE content. GPC analysis of the product from the three days reaction (Table 1) indicated that the product contained about 72\% PE. The monomer of PE; 9,10DHSA was detected to exhibits a molecular weight of $500 \mathrm{Da}$ in the GPC analysis, which is represented by component 3 of Table 1. The reported molecular weight values of GPC are PMMA equivalents as the GPC was calibrated with PMMA standards.

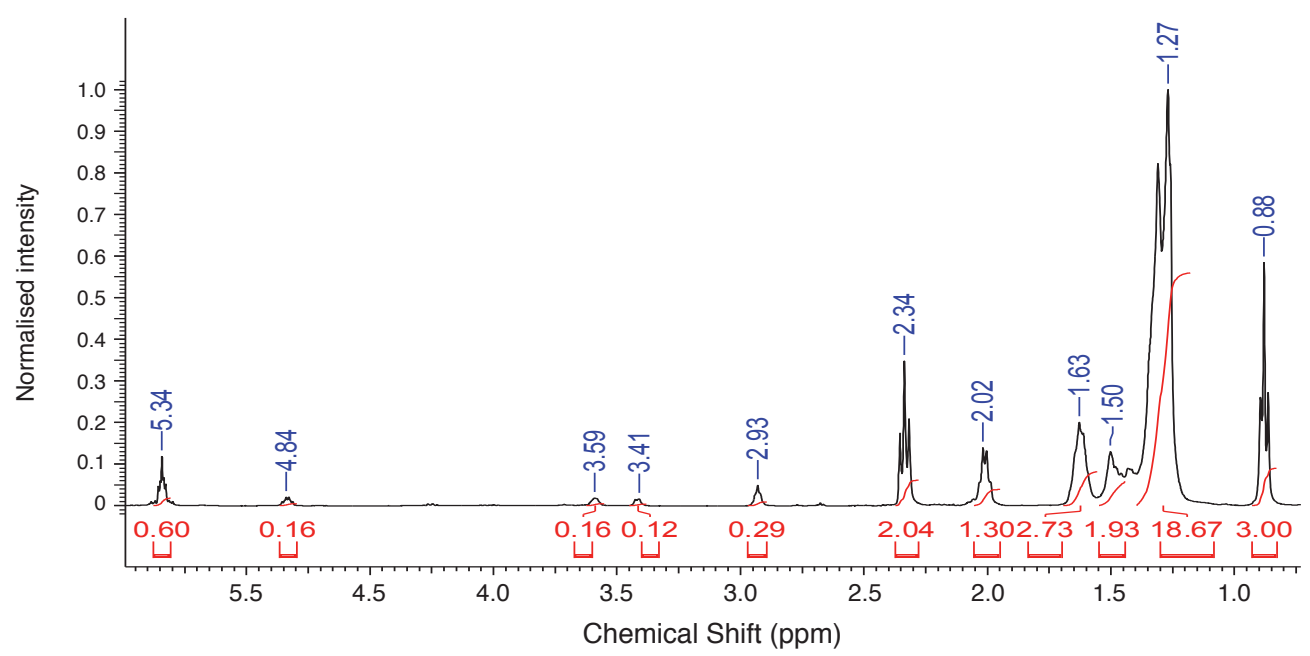

Figure 3. The $400 \mathrm{MHz}{ }^{1} \mathrm{H} N \mathrm{NR}$ spectrum of product from one day reaction in $\mathrm{CDCl}_{3}$.

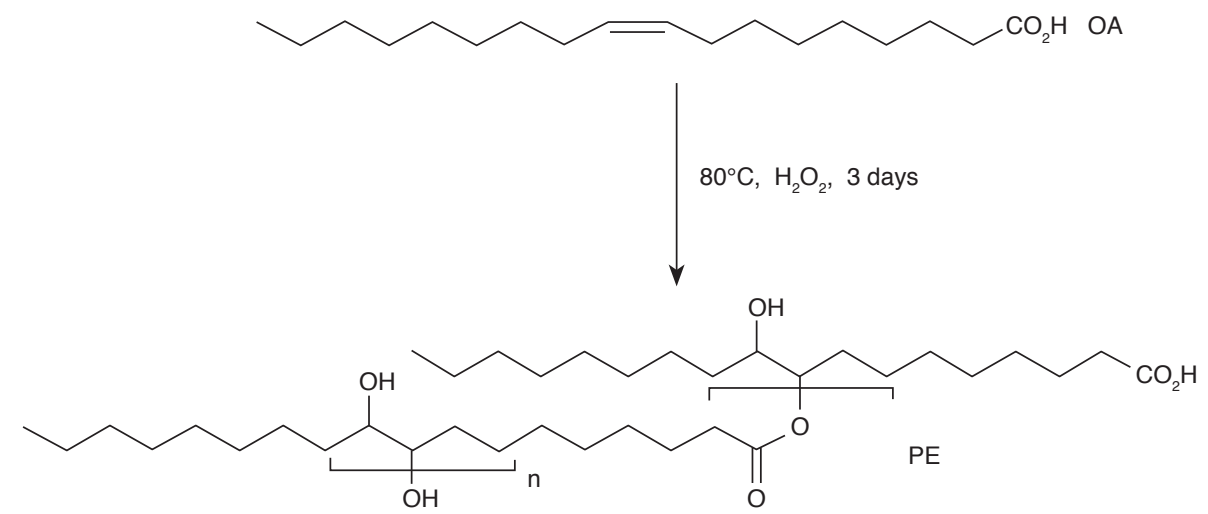

Figure 4. One-pot synthesis of idealised polyhydroxy estolides (PE) from oleic acid $(\mathrm{OA})$ in the presence of $\mathrm{H}_{2} \mathrm{O}_{2}$ without catalyst. 
TABLE 1. GEL PERMEATION CHROMATOGRAPHY ANALYSIS OF PRODUCT FROM ONE-POT SYNTHESIS OF POLYHYDROXY ESTOLIDES

\begin{tabular}{ccccc}
\hline Component detected & \multicolumn{2}{c}{ Gel permeation chromatography $(G P C)$} & \multirow{2}{*}{ Content (\%) } \\
\cline { 2 - 3 } & $\mathbf{M}_{\mathbf{w}}$ (Da) & $\mathbf{M}_{\mathbf{n}}(\mathrm{Da})$ & PDI & \\
\hline 2500 & 2200 & 1.13 & 46 \\
2 & 1050 & 1000 & 1.05 & 26 \\
3 & 510 & 490 & 1.04 & 28 \\
\hline
\end{tabular}

Note: $M_{w}$ - weight average molecular weight. $M_{n}$ - number average molecular weight. PDI - polydispersity index.

Referring to Table 1, component 1 can be assigned to tetramer of DHSA on the basis that a unit of DHSA is about $500 \mathrm{Da}$ as detected by GPC. Meanwhile, component 2 can be identified as dimer of DHSA on the same basis.

The AV and $\mathrm{OHV}$ of the prepared PE were $90 \mathrm{mg} \mathrm{KOH} \mathrm{g}^{-1}$ and $104 \mathrm{mg} \mathrm{KOH} \mathrm{g}^{-1}$ respectively. According to a literature reported by Awang et al. (2007), the AV can be used to estimate the degree of oligomerisation of PE known as estolides number (EN) by using Equations (1) and (2):

Neutralisation equivalent, $\mathrm{NE}=(1000 \times 56.1) /$

$$
\text { acid value }
$$

Estolides number, $\mathrm{EN}=(\mathrm{NE}-316.47) / 316.47$

Based on the AV of the prepared PE, the calculated EN of the prepared PE was 0.97, which showed that the prepared PE was a monoestolides, in other words, a dimer of DHSA.

Fourier transform infra-red (FTIR) spectrum of the prepared PE (Figure 5) shows carbonyl stretching of ester moiety at $1732 \mathrm{~cm}^{-1}$ that indicates the presence of ester linkages in the product. The carbonyl of carboxylic acid is clearly visible at 1708 $\mathrm{cm}^{-1}$ while the hydroxyl group is represented by peak at $3381 \mathrm{~cm}^{-1}$. Moreover, the FTIR spectrum also shows the absence of alkene and epoxide groups at $1600-1680 \mathrm{~cm}^{-1}$ and $800-850 \mathrm{~cm}^{-1}$ respectively. The data from FTIR analysis strongly suggest the formation of PE from OA.

Figures 6 and 7 are the $400 \mathrm{MHz}{ }^{1} \mathrm{H}$ NMR spectrum and ${ }^{1} \mathrm{H}-{ }^{1} \mathrm{H}$ COSY NMR spectrum of the prepared PE respectively. Figure 6 shows two peaks that correspond to methine protons attached to a carbon atom of a hydroxyl group $(\mathrm{HO}-\mathrm{C}-\mathrm{H})$ and an ester group $(\mathrm{O}=\mathrm{C}-\mathrm{O}-\mathrm{C}-\mathrm{H})$ at $3.6 \mathrm{ppm}$ and $4.82 \mathrm{ppm}$ respectively. Furthermore, COSY NMR analysis (Figure 7) showed that both peaks were coupled to each other, which imply that both methine protons were next to each other as depicted in the proposed idealised structure of PE (Figure 4). The same ester methine and alcohol methine protons were observed by Awang et al. (2007) in their ${ }^{1} \mathrm{H}$ NMR spectrum of DHSA-based PE.

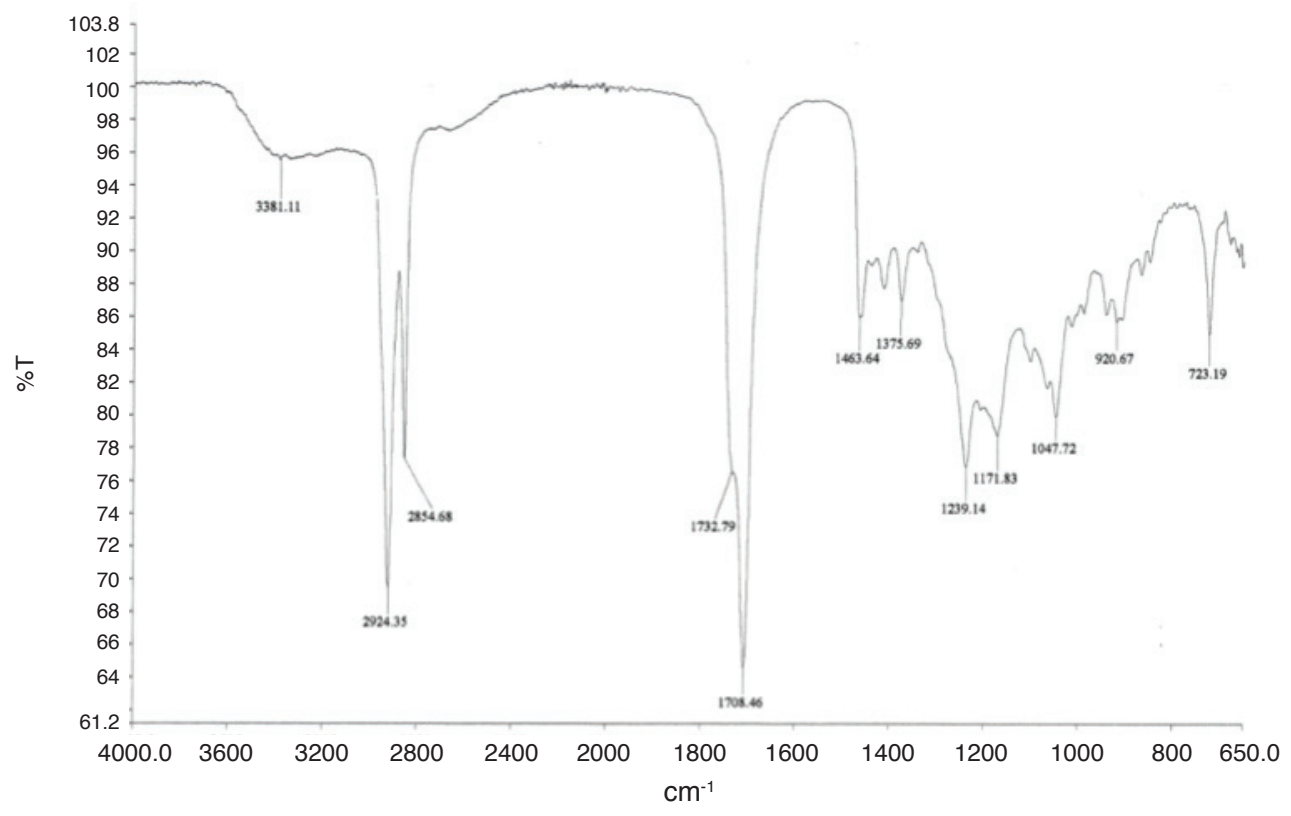

Figure 5. Fourier transform infra-red (FTIR) spectrum of prepared polyhydroxy estolides (PE). 


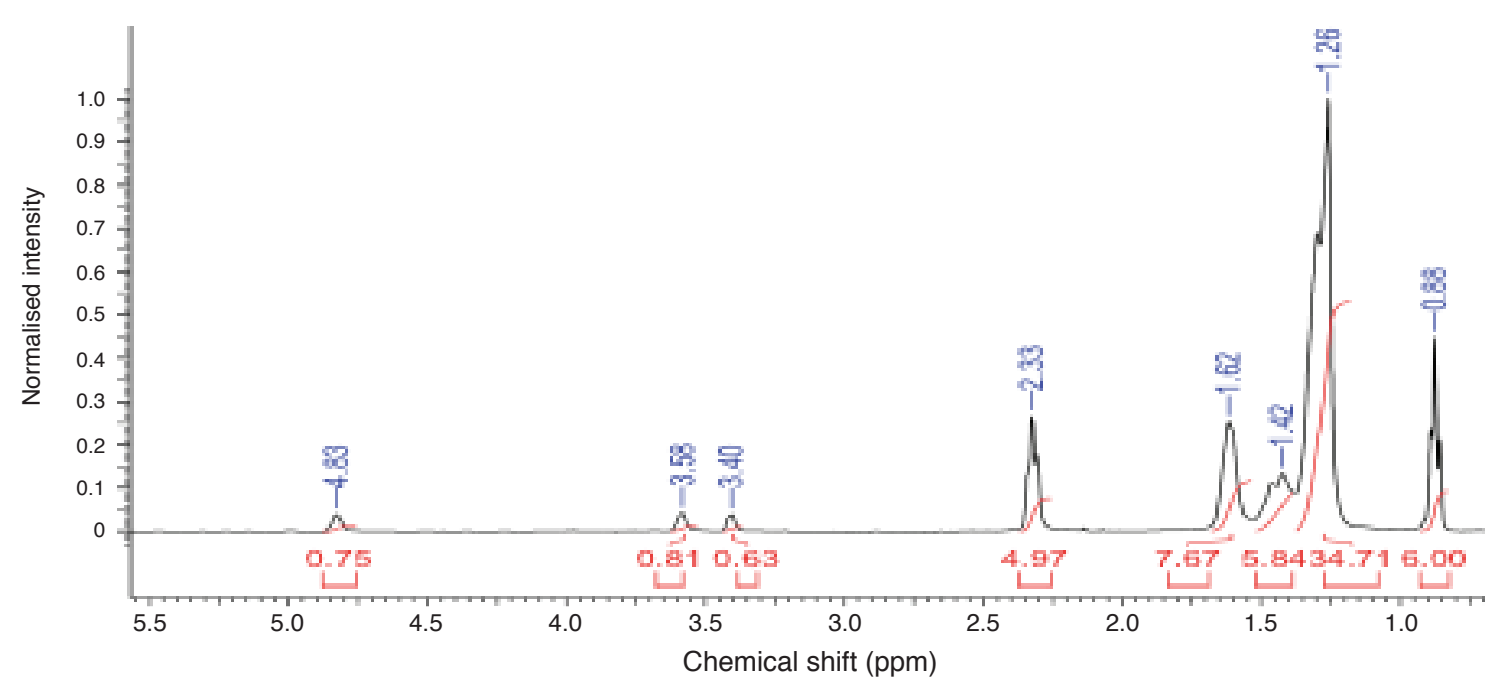

Figure 6. The $400 \mathrm{MHz}{ }^{1} \mathrm{H} N \mathrm{NR}$ spectrum of polyhydroxy estolides (PE) in $\mathrm{CDCl}_{3}$.

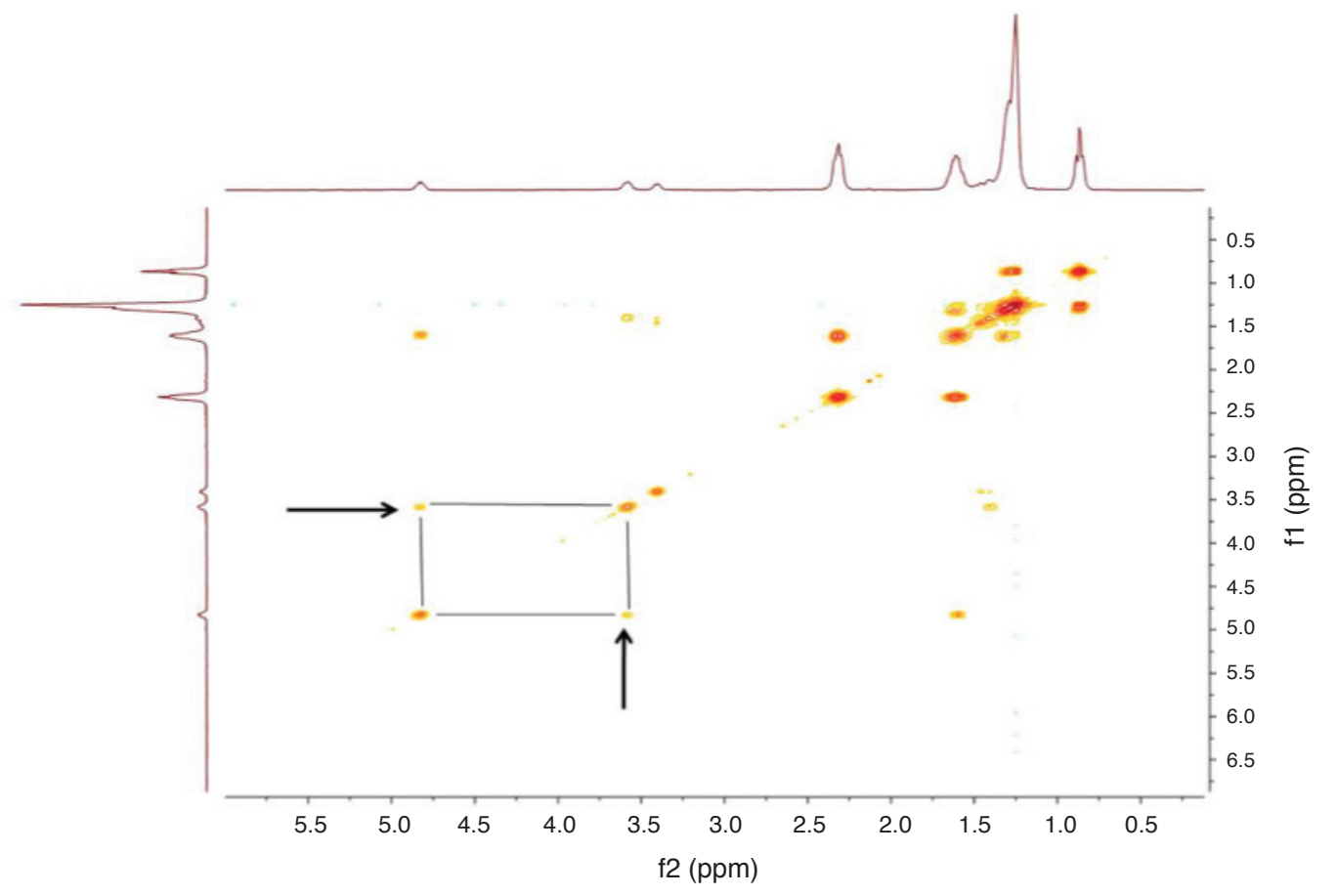

Figure 7. The $400 \mathrm{MHz}{ }^{1} \mathrm{H}^{-1} \mathrm{H}$ COSY NMR spectrum of polyhydroxy estolides (PE) in $\mathrm{CDCl}_{3}$.

In addition, the ${ }^{1} \mathrm{H}$ NMR spectrum of prepared $\mathrm{PE}$ also shows the absence of alkene group of $\mathrm{OA}$ at $5.34 \mathrm{ppm}$, which supports the hypothesis that the alkene group was converted to epoxide group in the presence of hydrogen peroxide. Moreover, the same spectrum also shows the absence of epoxide group at $2.93 \mathrm{ppm}$ that indicates all oxirane ring was opened to form ester and hydroxyl groups.

The ${ }^{13} \mathrm{C}$ NMR analysis of the prepared PE showed two types of carbonyl at $179 \mathrm{ppm}$ and 174 ppm respectively (Figure 8). The carbonyl at 179 ppm represents carboxylic acid group while the carbonyl at $174 \mathrm{ppm}$ can be assigned to ester group of PE. Furthermore, the ${ }^{13} \mathrm{C}$ NMR spectrum also shows three types of $\mathrm{C}-\mathrm{O}$ carbons at $76.3,74.6$ and $72.5 \mathrm{ppm}$. The peak $76.3 \mathrm{ppm}$ is a $\mathrm{C}-\mathrm{O}$ bond of ester group, while the $72.5 \mathrm{ppm}$ peak is the $\mathrm{C}-\mathrm{O}$ bond of alcohol group adjacent to the ester group. Meanwhile, the $74.6 \mathrm{ppm}$ peak can be assigned to alcohol groups of DHSA moiety.

MALDI-TOF-MS analysis of the prepared PE (Figure 9) showed oligomers of oleic acid with molecular weight of $1829 \mathrm{Da}$, which corresponded to sodium adduct of hexamer of oleic acid. The repeating unit of the oligomer has a molecular weight of $298 \mathrm{Da}$, which corresponded to structure depicted in Figure 10. The 636, 934, 1233 and 1531 Da peaks represent sodium adduct of dimer, trimer, tetramer and pentamer of DHSA respectively.

The NMR and MALDI-TOF analysis results confirmed that OA can self-oligomerised in a onepot system without any catalyst. The proposed reaction pathway for self-oligomerisation of $\mathrm{OA}$ is illustrated in Figure 11. The OA was oxidised to oleic 


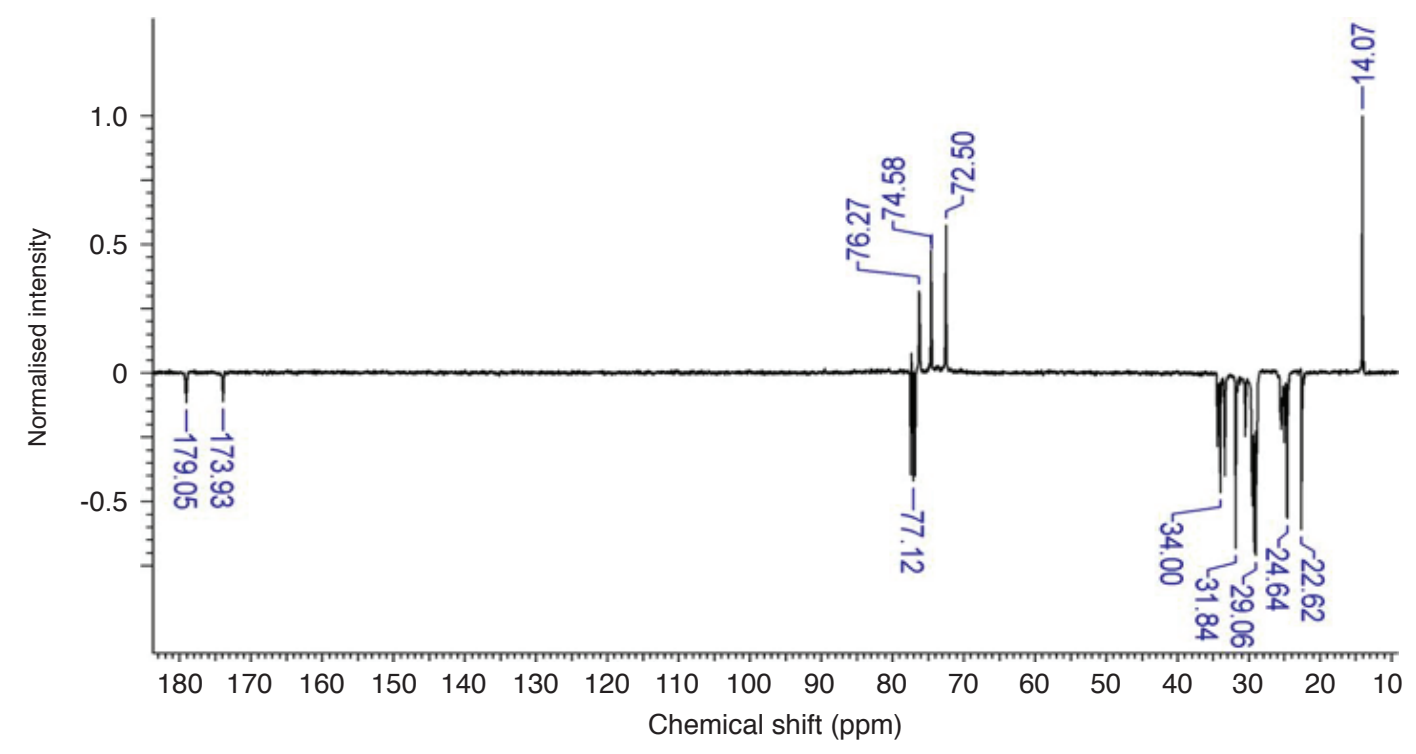

Figure 8. The $100 \mathrm{MHz}{ }^{13} \mathrm{C}$ NMR spectrum of polyhydroxy estolides (PE) in $\mathrm{CDCl}_{3}$.

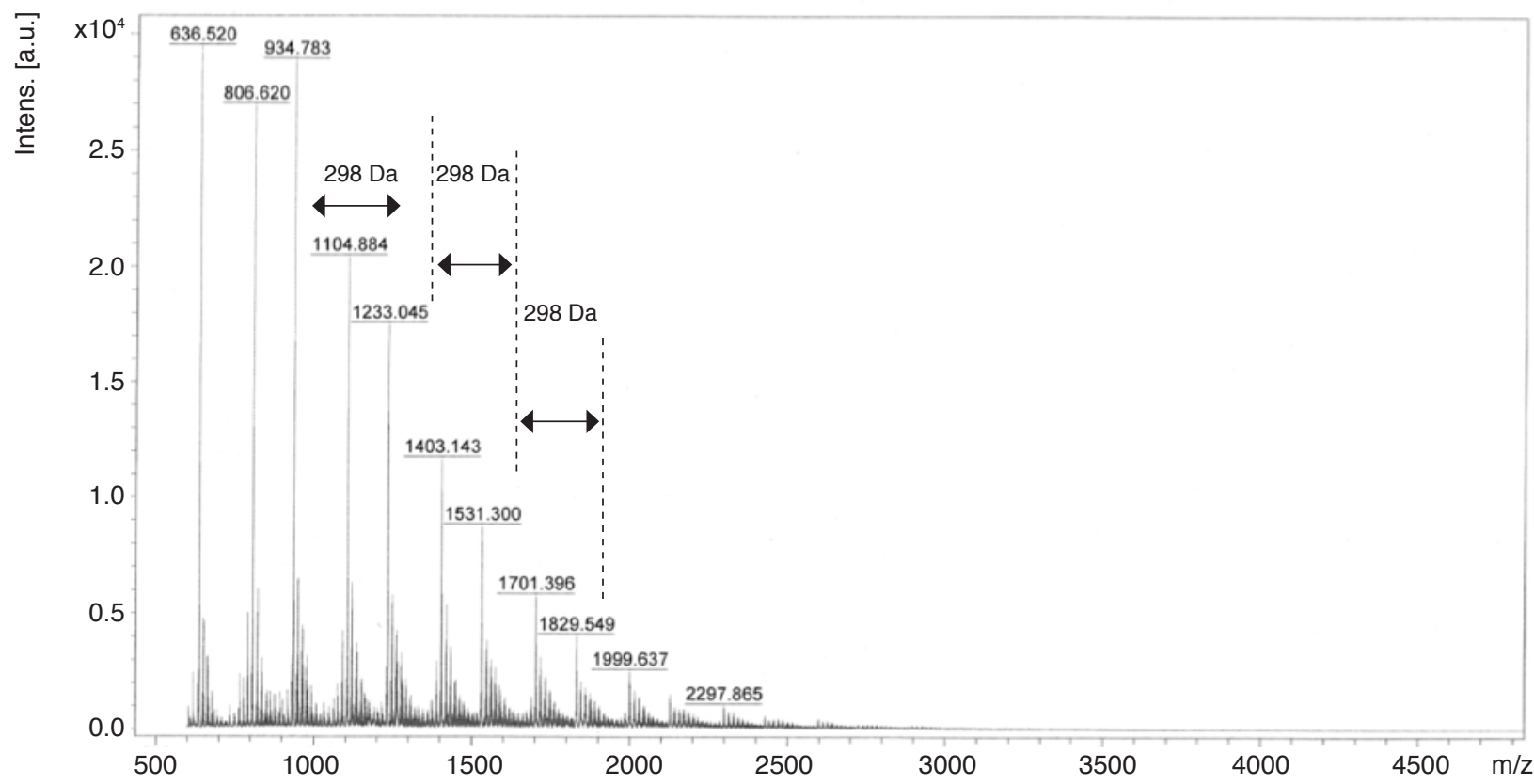

Figure 9. The MALDI-TOF-MS spectrum of polyhydroxy estolides (PE) by using dihydroxybenzoic acid (DHB) as the matrix in the analysis.

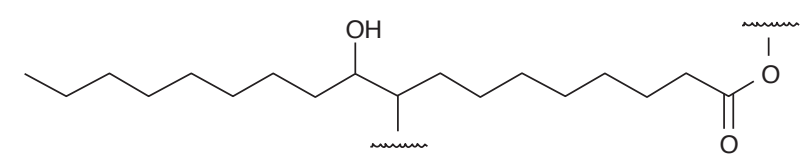

Figure 10. Repeating unit of polyhydroxy estolides (PE).

peracid (OP) by $\mathrm{H}_{2} \mathrm{O}_{2}$ and the newly formed OP was then able to epoxidise another OA molecule to yield epoxidised oleic acid (EOA). The epoxide group of EOA was eventually ring-opened by the carboxylic acid group of another EOA and this process repeat itself to yield the desired PE. The epoxide ring opening by the carboxylic acid group can take place at either carbon 9 or 10 of the epoxide group and this generates PE with regioisomers of carbon 9 or 10. The idealised structure of PE can be illustrated by Figure 11.

The other possible chemical compound that could be produced from the oligomerisation reaction of $\mathrm{OA}$ is an ether oligomer (EO) where a hydroxyl group has reacted with an epoxide instead of a carboxylic acid. This alternative product will have the same mass ion as discussed above for PE. The possible idealised chemical structure of EO is illustrated in Figure 12, which is an oligomer of oleic acid linked by ether functionality.

This oligomer could be produced when the oxirane group of EOA acid was ring opened by water 


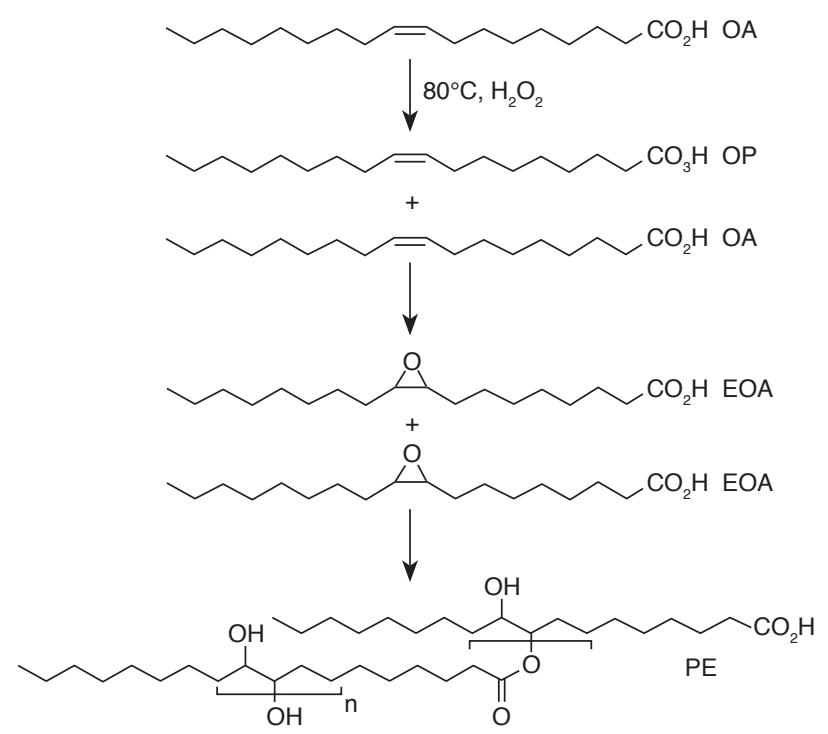

Figure 11. Proposed reaction pathway for self-oligomerisation of oleic acid $(\mathrm{OA})$ without catalyst in $\mathrm{H}_{2} \mathrm{O}_{2}$ to yield idealised structure of polyhydroxy estolides (PE).

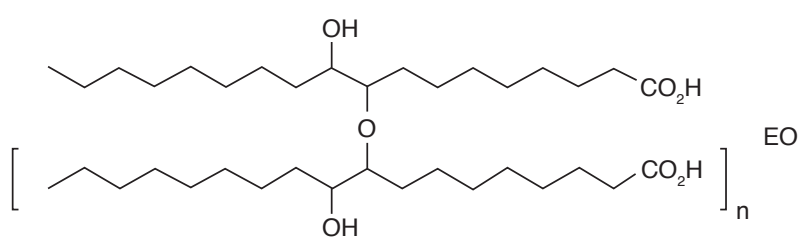

Figure 12. Idealised oligomers of oleic acid linked by ether functionality.

to yield initially a dihydroxy group (HO-C-C-OH) and then one of the newly formed hydroxy groups can attack the oxirane of another EOA molecule to form an ether linkage between the two fatty acid chains. The other hydroxy group could repeat this process and form higher oligomers.

\section{Reduction and Saponification of Polyhydroxy Estolides (PE)}

In order to further confirm the chemical structure of $\mathrm{PE}$ and rule out the formation of $\mathrm{EO}$, the PE was subjected to two reactions, namely reduction with $\mathrm{LiAlH}_{4}$ and saponification with $\mathrm{NaOH}$. The $\mathrm{LiAlH}_{4}$ is a strong reducing agent and it is capable of reducing ester bonds to alcohols. Therefore, when PE was subjected to reduction with $\mathrm{LiAlH}_{4^{\prime}}$ the ester linkages between the repeating units of OA should be broken and reduced to alcohol groups (causing depolymerisation). If, however, the linkages between the monomers were ether linked, then the compound would not be reduced to monomer. The same concept applies to the saponification reaction, where the ester linkages between monomer will be cleaved by $\mathrm{NaOH}$ but will not be cleaved if the linkages between monomer were ether groups.
When PE was subjected to saponification and the crude product was purified by column chromatography, the major product produced from the reaction was 9,10-DHSA. Reduction reaction of $\mathrm{PE}$ with $\mathrm{LiAlH}_{4}$ gave 1,9,10-THS as the major product (Figure 13). Both reactions indicated that the linkages between oleic acid units were the expected ester linkage and ruled out an ether linkage.

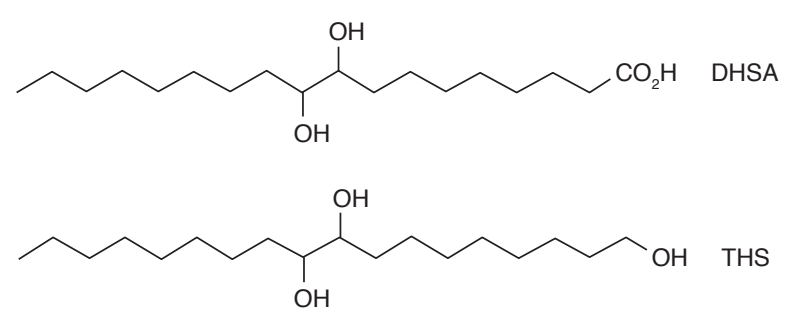

Figure 13. Major products from saponification and reduction of polyhydoxy estolide (PE).

\section{CONCLUSION}

PE can be prepared from OA through one-pot selfoligomerisation of oleic acid without any catalyst, in which the OA was 'self-epoxidised' by the peracid formed in situ from reaction between $\mathrm{OA}$ and $\mathrm{H}_{2} \mathrm{O}_{2}$. The EOA was then ring opened by another OA to yield $72 \%$ PE with number average molecular weight of the oligomers in between $1000-2200$ Da. Instrumental and wet analyses revealed that the prepared PE was linked by ester groups and further confirmation of the oligomers structure was achieved by reduction and saponification reactions. PE were successfully prepared from oleic acid through a simple non-catalytic one-pot process at a lower temperature, which significantly reduce the production cost of $\mathrm{PE}$ as compared to current methods. The PE can be used as emulsifier for cosmetic and personal care products.

\section{ACKNOWLEDGEMENT}

The authors thank the Director-General of MPOB for permission to publish this article and for the funding of this research project. The authors would also like to express their gratitude to colleagues in Advanced Oleochemical Technology Division, MPOB who contributed to the completion of this study.

\section{REFERENCES}

AMERICAN OIL CHEMISTS' SOCIETY (AOCS) (2009). Acid value (Te 1a-64); hydroxyl value (OHV), Cd I3-60(89). Official Methods and Recommended Practices of the American Oil Chemists' Society. $6^{\text {th }}$ Edition., AOCS Press, Champaign, Illinois, USA. 
AWANG, R; AHMAD, S; KANG, Y B and ISMAIL, R (2001). Characterization of dihydroxystearic acid from palm oleic acid. J. Amer. Oil Chem. Soc., 78(12): 1249-1252.

AWANG, R; NOR AZIZAN, A; AHMAD, S and WAN YUNUS, W M Z (2007). Characterization of estolides from dihydroxystearic acid. J. Oil Palm Res. Vol. 19: 350-355.

CERMAK, S C and ISBELL, T A (2001). Synthesis of estolides from oleic acid and unsaturated fatty acids. J. Amer. Oil Chem. Soc., 78(6): 557-565.

HAYES, D G and KLEIMAN, R (1995). Lipasecatalyzed synthesis and properties of estolides and their esters. J. Amer. Oil Chem. Soc., 72(11): 1309-1316.

ISBELL, T A and CERMAK, S C (2002). Synthesis of triglyceride estolides from lesquerella and castor oils. J. Amer. Oil Chem. Soc., 79(12): 1227-1233.

ISBELL, T A; KLEIMAN, $\mathrm{R}$ and PLATTNER, B A (1994). Acid-catalysed condensation of oleic acid into estolides and polyestolides. J. Amer. Oil Chem. Soc., 71(2): 169-174.

ISMAIL, R; AWANG, $\mathrm{R}$ and HASSAN, A $\mathrm{H}$ (2015). Palm dihydroxystearic acid (DHSA): a multifunctional ingredient for various applications. J. Oil Palm Res. Vol. 27(3): 195-211.
JULIETTI, F J; MCGHIE, J F; RAO, B L; ROSS, W A and CRAMP, W A (1960). Aliphatic acids. Part II. Some aliphatic epoxy-acids and related compounds. J. Chemical Society: 4514-4521.

KIATSIMKUL, P; SUPPES, G J; HSIEH, F; LOZADA, Z and TU, Y (2008). Preparation of high hydroxyl equivalent weight polyols from vegetable oils. Industrial Crops and Products, 27(3): 257-264.

MCKAY, A F and BADER, A R(1948). The preparation and properties of the eight diastereoisomers of 9,10,12,13-tetrahydroxystearic acid. J. Org. Chem., 13(1): 75-85.

MODAK, S N and KANE, J G (1965). Studies in estolides. I. kinetics of estolide formation and decomposition. J. Amer. Oil Chem. Soc., 42(5): 428432.

PAGES, $X$ and ALFOS, C (2001). Synthesis of new derivatives from vegetable sunflower oil methyl ester via epoxidation and oxirane opening. Oleagineux Crops Gras Lipides, 8(2): 122-125.

WARWEL, S and KLAAS, M R (1995). Chemoenzymatic epoxidation of unsaturated carboxylic-acids. J. Molecular Catalysis B: Enzymatic, 1: 29-35.

ZERKOWSKI, J (2008). Estolides: from structure and function to structured and functionalized. Lipid Technology, 20(11): 253-256. 